\title{
Hologram Technology as Interactive Space Design in Tugu Pahlawan Museum Surabaya
}

\author{
Michael Yudhistira Miandda \\ Architecture Department \\ Petra Christian University \\ Surabaya, Indonesia \\ m22415163@john.petra.ac.id
}

\author{
Felix Sulistio Tjiang \\ Architecture Department \\ Petra Christian University \\ Surabaya, Indonesia \\ m22415158@john.petra.ac.id
}

\author{
Leonardo Gunady \\ Architecture Department \\ Petra Christian University \\ Surabaya, Indonesia \\ m22415127@john.petra.ac.id
}

\begin{abstract}
Tugu Pahlawan Museum is built on a concept to help the citizen gain knowledge about their city. On the contrary, the information that has been delivered did not have any changes in the system throughout the years, so it is hard for the citizen to understand the visualization and experience in this museum with the current technology, which made them lose their interest to visit this museum. Seeing this situation, an idea arose to use holographic-based technology as a breakthrough in solving the problem. The idea of delivering information in the form of hologram is expected to attract people to look back on history of Surabaya city in different perspective.
\end{abstract}

Keywords : Hologram, Tugu Pahlawan Museum, Experience, Interactive Museum, Technology, Native Citizen

\section{INTRODUCTION}

In this modern era, the existence of museums is not very much in demand by most people in Indonesia in the delivery of information. The Director of Preservation of Cultural Heritage and Museum Harry Widianto also acknowledged that the enthusiasm of the community was still lacking. "It could be because the museum's physical condition is not all that good, it could also be because the museum's presentation still seems rigid. In reality the physical building of the museum throughout Indonesia, not all of them are in good condition. Therefore, the visit and interest of the community become uneven," he said. (https://travel.kompas.com/read/2014/11/23/1102002/Mu seum.di.Indonesia.Masih.Minim.Peminat)

The loss of interest of Indonesian people in visiting the museum is inseparable from the influence of technology which is growing rapidly. As a result of the development of this technology, all information can be obtained easily. In this globalization era, most people prefer to use technology to get information. By applying technology into this museum, visitors will be more interested in using it.

The application of hologram technology in the present is still fairly rare. It is only used as fillers in a room in a building, or become an exhibition, some for shows such as malls in Dubai, but the application of the hologram does not involve the architecture of the mall. Surabaya is a city that labeled as a historical city which had a lot of history, but the interest of museum visitors is not comparable. Based on the data of museum visitors in Indonesia (Data Processing Center and Network System, Depdubpar 2009), Surabaya has a low visit rate compared to other cities in Indonesia. By applying the hologram to the museum, this will be a new breakthrough to attract visitors to get to know the history of Surabaya again.

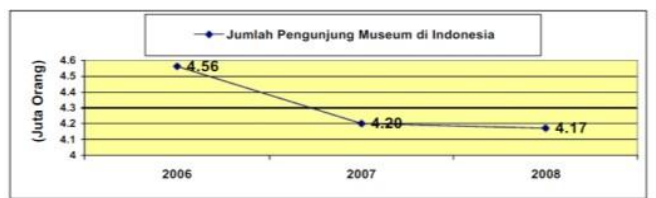

Figure 1. The Graphic of Museum Visitors In Indonesia. (Source:https://id.scribd.com/doc/174566667/3Jumlah-PengunjungMuseum-Di-Indonesia)

Surabaya called Kota Pahlawan which has a lot of history and has the potential to attract the public to see it, with the renewal of advanced technology enabling people to be more enthusiastic to visit the Tugu Pahlawan museum.

\section{LITERATURE REVIEWS}

A. Study Precedent

1. Zoning

Based on the design of Tugu Pahlawan Museum, the building is divided into several zoning, which is electronic diorama, surabaya after proclamation zone, the battle of surabaya during and post battle zone and static diorama. Every zone inside the building describe the history of surabaya which support the purpose of the building itself as a historical museum.

2. Space Design

On the second floor of the museum, 8-meter high building, there is a round circulation circling the main void with 5.5 meters path's wide, and there is a display table that surround half of the void with 1 meters wide. On each corner of the floor, there is a glass prism display. In the middle of the main voids there is a large prism pointing down and on each side of it there is information about the history of heroes. And there is also a disability lift, and two static diorama sp

aces with an 8 -square shape with a diameter of 6 meters. 


\section{Building Material}

The second floor use ceramics as the floor material, and brick as the wall material with several areas covered with wood. Columns and beams use ordinary concrete in general, skylights contained in a Static Diorama Room on the second floor using polycarbonate material, so that it absorbs almost $90 \%$ of the sun's rays and make the room remains bright. The display of antiques in the prism using a glass cover. The shape was made into prism to make it more dynamic.

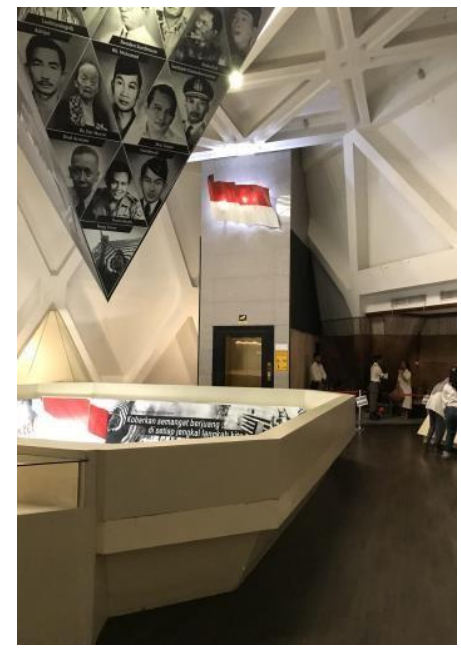

Figure 2. The Second Floor Design of the Tugu Pahlawan Museum. (Source: Primary Data)

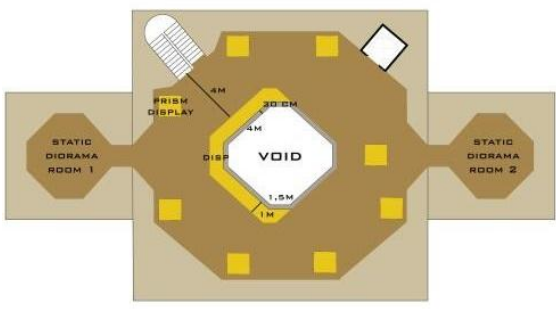

Figure 3. Tugu Pahlawan

Museum's Second Floor Plan Before Redesign

(Source: Primary Data)

4. Science Concept (color, lighting and ventilation)

a. Color

The color of the building differs based on the material they used. The structure of the Tugu Pahlawan Museum is exposed yet painted in white to make the design cleaner and less rough.

b. Lighting

Tugu Pahlawan Museum focused their lighting on the top of the building, using skylight to let the sun light enters the room and being reflected to every corner in the room. Active lighting were added to brighten the historical relic making it noticeable and easy to observe.

c. Ventilation

Most of the room used active airing, air conditioner, to cool down rooms and corridor inside Tugu Pahlawan Museum as the building didn't have any opening from the beside.

5. Technology Inside the Building.
The Tugu Pahlawan museum deliver its knowledge and information through maquette as a model in showing everything that happened in the past with the intention to make it easier to understand. Beside maquette, they added sound effect inside the room to maximize the experience of Surabaya history. Inside the museum lies a statue as a marker of Tugu Pahlawan museum. On the top of the statue, there is a skylight that make it a spotlight in the middle of the museum to indicate the museum purpose.

B. Hologram design and application to buildings

1. How Hologram Technology Works Hologram is the process of displaying images due to the mixing of the two laser beams on one surface. There are two laser beams called the Reference Beam, the light that does not bounce off the object, and the Beam Object's light bounces and hits the object.

There are two types of hologram applications, Transmission Hologram and Hologram Reflection. Transmission

Holograms are formed because of the Reference Beam and the Object Beam that collide on one holographic surface.

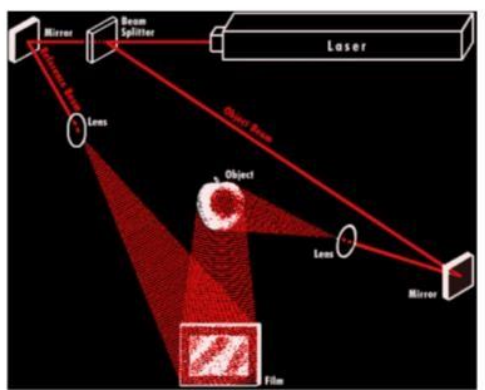

Figure 4. The Transmission Hologram Work Principle (Source: http://www.insinyoer.com/prinsipkerja-hologram/)

The Mixing between Reference Beam and Object Beam will produce a reconstruction image on the side that is not exposed to the light.

Second is the Hologram Reflection. This hologram has a difference in displaying reconstruction images. In this system, the reference beam and object ray will meet on the opposite side of the hologram surface. The image shown will be on the side that collides with the reference beam.

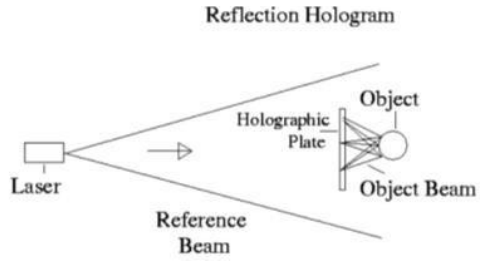

Figure 5. Reflection Hologram Work Scheme (Source: http://www.insinyoer.com/prinsipkerja-hologram/)

In Hologram Reflection, the reconstruction image is a reflection between the mixing of the reference beam and the object's light on the hologram's surface. In this system, the image created will be sharper and almost indistinguishable from the original object.

2. Application in architectural design (adapted form) 
To show what really happened in the past, museum can only make the scenes with videos technology.

Newer technology can be applied through a miniature. From the results of our research, there is a tool that can display holographic images with interactive in the form of a miniature namely the Holus Box.

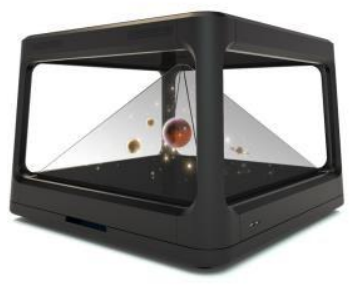

Figure 6. Holus Box.

(Source: https://hplustech.com/)

By utilizing the pyramid shape, we see that holograms can become more real so that they get a wider view for users.

\section{PROBLEM STATEMENTS}

What causes the lack of interest of the Indonesian population in visiting the museum?

How can the impact of technological development be applied to the design of the museum so that people are more interested? What is the mechanism of applying technology in museum design?

What impact has this resulted from applying modern technology into museum design in terms of architecture and commercial terms?

\section{METHODOLOGY}

Data collection was done by surveying and observing the Holus Box modeling literature study because it had a match with the shape of the space and by visiting the Hero Monument Museum, we had record the data through photos and sketches. We also did some experiment with hologram models that have the same working method as the holus box and will be applied in the design.

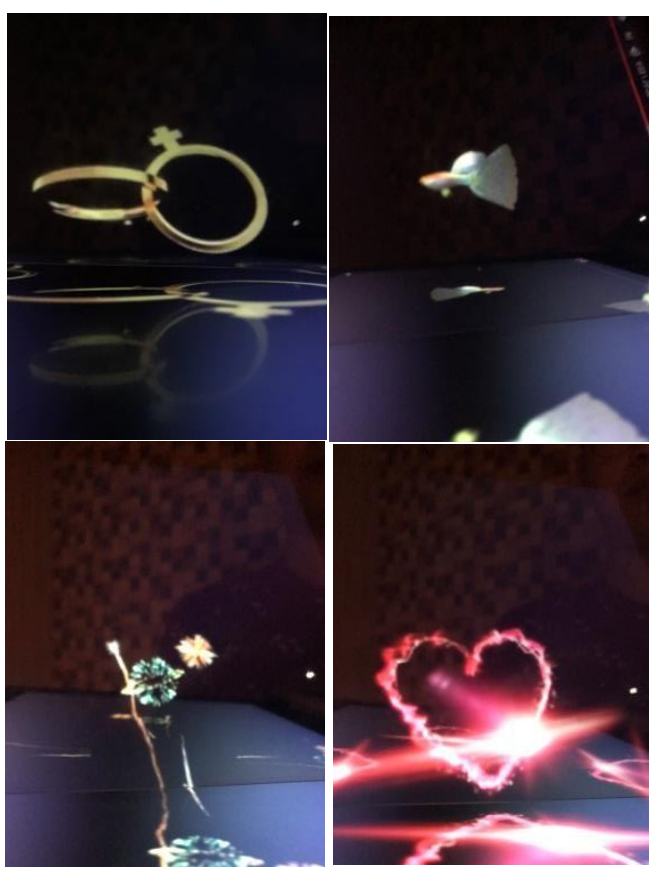

Figure 7. Hologram Experiment Model (Source: Primary Data)

\section{RESULT OF ANALYSIS}

In order to raise the public interest, we came up with an idea to use the holographic technology as a new breakthrough that rarely seen in any other museum. The idea of using holographic technology based on public's interest nowadays, which is a modern technology. The application of holographic technology will take place in the second floor of the museum, which is on the void of the second floor and on the circulation area. There are two kinds of the holographic technology that will be used in this museum.

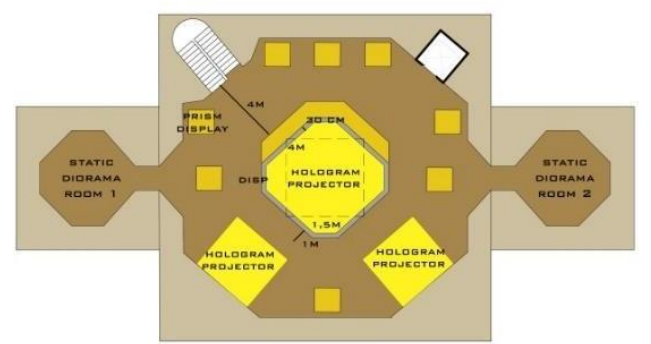

Figure 8. Tugu Pahlawan Museum's Second Floor Plan After Redesign (Source: Primary Data)

The first one is to use the same holographic technic as the holus box. The technique of the holus box is to project the image from the to of the pyramid and reflect it to the pyramid wall, so it can be seen from the outside of the box as a 3D shaped object. This technique will be applied to the holographic technology on the void of the second floor. 


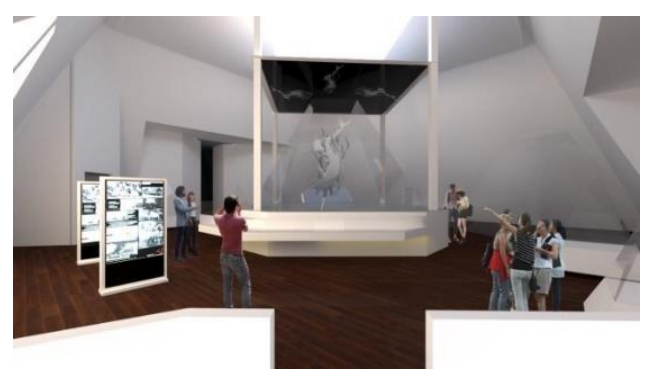

Figure 9. Holographic Projector Which Based on Holus Box

(Source: Primary Data)

The other holographic technique will be placed in the circulation of the floor. The technique is to make the visitor enter the holographic box to get more intimate experience to the story. In order to do that, the projector will be placed under the pyramid box, so it can project the image to the inside part of the pyramid wall and the 3D object would be made inside the box.

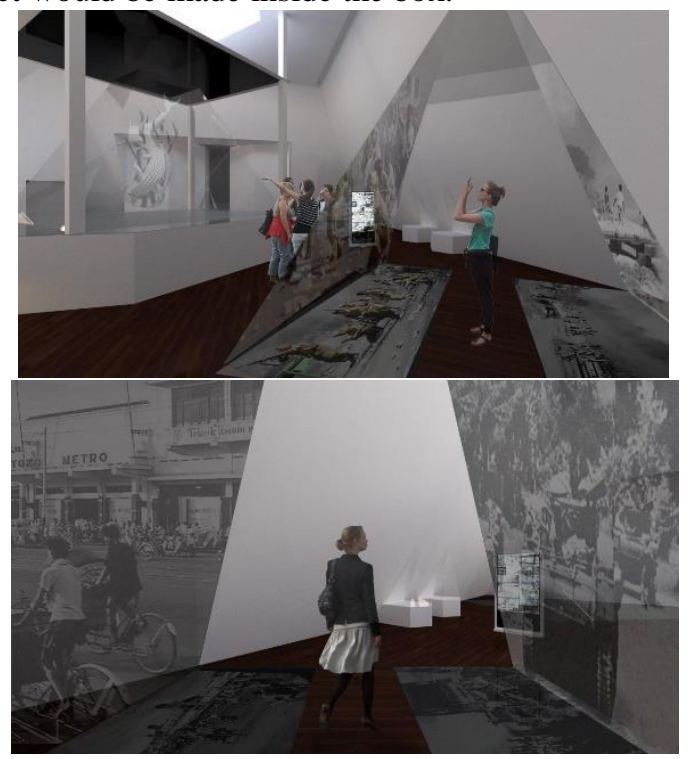

Figure 10. History Showed Through a Hologram (Source: Primary Data)

\section{DISCUSSION}

Tugu Pahlawan Museum slowly lose it's fame after time to time. The museum is no longer busy as usual. The public started losing their interest because of the system inside the museum didn't change and it makes them bored. The usual museum design only makes the visitor imagine of what happened in the past through the maquette and sound system explained the maquette. To make it more interactive, the museum adds an old video to show the past to the visitor. The monotone system of the museum makes people already expect what would happened inside the museum.

To prevent the public from leaving the museum, there comes an idea to make change to the museum design. The museum design needs to follow the trend in order to make the people interested to it. Holographic technology is the most advanced technology nowadays in the IT's world, but it never applied in the museum, though it's really related.
So we use the idea of hologram system to the Tugu Pahlawan Museum design. We hoped that with the new advanced technology added to the museum, it makes the public taken their interest in coming to the museum again.

\section{CONCLUSION}

From the experiment that we do, the Tugu Pahlawan museum design is fully capable in applying the hologram technology inside it. Beside the fact that there is a plenty space in the second floor, which the reconstruction took place, the pyramid design of the museum's interior can make the holographic box blend in to the design and makes it looked like it was a part of he building design.

As it is explained before, the hologram technology will be a new breakthrough in a museum design. It goes well with the public as it is what entertained them in this modern era. This paper explained that the museum should change their appearance from time to time so that the public will keep visiting them with being bored.

\section{ACKNOWLEDGMENT}

We are really grateful to be able to completed our paper about the re-design of Tugu Pahlawan Museum using the hologram technology. This paper cannot be completed without the effort and co-operation between our members group, Michael Yudhistira Miandda, Felix Sulistio Tjiang, and Leonardo Gunady. We would also like to offer our sincere gratitude to our mentor and lecturer, Rully Damayanti, S.T., M.Art., Ph.D. and Angela Christysonia Tampubolon S.T., M.T., for guiding and encouraging us in finishing this paper. Lastly, we want to thank our friends and everyone that had helped us in completing this paper.

\section{REFERENCES}

E. Bogle, Museum Exhibition Planning and Design. AltaMira Press, UK : Rowman and Littlefield Publishing Group, Inc, 2013.

Holografi. (2017). Retrieved July 26, 2018 from https://id.wikipedia.org/wiki/Holografi

Husaini, Nur Achmad. (2015, November 8). Prinsip Kerja Hologram. Retrieved from http://www.insinyoer.com/prinsip-kerjahologram/

H+Technology.(n.d.). Retrieved July 26, 2018 from https://hplustech.com/

Noviyanti, Sri. (2014, November 23). Museum di Indonesia Masih Minim Peminat. Retrieved from https://travel.kompas.com/read/2014/11/23/1 102002/Museum.di.Indonesia.Masih.Minim. Peminat

Wahyu, Syarif. (n.d.). -3-Jumlah Pengunjung Museum Di Indonesia. Retrieved from https://id.scribd.com/doc/174566667/3Jumlah-Pengunjung-Museum-Di-Indonesia 